Елена Стошич

Универзитет у Новом Саду

Филозофски факултет

jelenashargi@gmail.com

Ольга А. Трапезникова

Кемеровский государственный институт культуры

Кемерово, Российская Федерация

trapeznikova-olg@mail.ru
УДК 811.161.1'373.7:811.163.41'373.7 https://doi.org/10.18485/slavistika.2018.22.2.8 оригинални научни рад примљено 01.03.2018. прихваћено за штампу 04.10.2018.

\title{
СРАВНИТЕЛЬНО-СОПОСТАВИТЕЛЬНЫЙ АНАЛИЗ \\ РУССКИХ И СЕРБСКИХ УСТОЙЧИВЫХ ВЫРАЖЕНИЙ С ЗООНИМИЧЕСКИМ КОМПОНЕНТОМ «ЛОШАДЬ» («КОНЬ»)
}

Настоящая работа посвящена анализу зоонима «лошадь» в русской и сербской языковой картине мира. Образ лошади является одной из ключевых фигур в русских и сербских паремиях. Цель нашей работы - выявить как общие, так и уникальные особенности функционирования образа лошади в двух славянских языках. Материалом исследования служат русские и сербские паремии - пословицы, поговорки и фразеологизмы. Работа носит сопоставительный характер.

Ключевые слова: лошадь, конь, языковая картина мира, сербский язык, русский язык, паремии.

The purpose of this paper is the analysis of the zoonym «horse» in the Russian and Serbian worldview. Regarding lexemes representing animals, horse is one of the central figures in Russian and Serbian proverbs. The aim of this research is to determine the general as well as the particular qualities of the zoonym «horse» in Russian and Serbian proverbs. As research material, we used Russian and Serbian proverbs, sayings and idioms. During the analysis we used the comparative method.

Key words: horse, worldview, Serbian language, Russian language, proverbs.

Конь (лошадь) является одним из ключевых зоонимических компонентов в русских и сербских паремиях и фразеологизмах. Как известно, образные изречения и идиоматические выражения, лаконично репрезентирующие целый комплекс культурных смыслов, занимают особое место в языковой картине мира и содержат национально значимую информацию. Актуальность настоящего исследования обусловлена необходимостью сравнительно-сопоставительного анализа функционирования данной пары зоонимов в устойчивых выражениях двух славянских языков, что позволит выявить как общие, так и уникальные особенности их употребления.

Термин «зооним» трактуется в лингвистике широко и может использоваться для определения как собственных имен (кличек) животных (в ономасиологии), так и имен нарицательных, обозначающих животных (Ю.Г. Юсифов, Н.В. Солнцева, Л.Р. Сакаева, 3.А. Гордеева, А.А. Шолина, Д.С. Смирнова, Ж. Багана, Ю.С. Михайлова, Е.В. Кудрявцева и др.). В настоящей работе данный термин используется во втором значении.

Фразеологизмы - это «семантически связанные сочетания слов и предложений, которые воспроизводятся в речи в фиксированном соотношении семантической структуры и определенного лексико-грамматического состава» (ЛЭС

Славистика XXII/2 (2018) 
1990). В науке выделяются два подхода к определению границ данного понятия. При узком подходе к фразеологизмам относятся только единицы, эквивалентные словам (номинативные). При широком подходе в их состав входят и единицы, в семантическом и структурном отношении соответствующие предложению (коммуникативные): пословицы, поговорки, афоризмы и т.д. Однако вопрос об отнесении последних к фразеологизмам решается неоднозначно. Вслед за В.М. Мокиенко, фразеологизм трактуется нами как «относительно устойчивое, воспроизводимое, экспрессивное сочетание лексем, обладающее (как правило) целостным значением» (Мокиенко 1989). Пословицы и поговорки рассматриваются нами как паремии.

Материалом исследования служат 110 русских и 75 сербских устойчивых выражений с зоонимическим компонентом «конь» («лошадь»), собранных из словарей В. Даля, В. Караџића, В.М. Мокиенко, Дж. Оташевића, В.П. Жукова методом сплошной выборки.

Лексемы «конь» и «лошадь» в русском языке являются базовыми зоонимами, обозначающими «парнокопытных животных семейства лошадиных». В сербском языке им соответствуют лексемы «коњ» и «кобила», противопоставленные по признаку пола. В русском же языке данный признак не является регулярным (ср. загнанный конь и загнанная лошадь, ломовая лошадь и редко ломовой конь). Как отмечает Химик В. В., «оппозиция лошидь - конь основана на двух прагматических противопоставлениях»: 1) нейтральность - окрашенность: лошадь обладает нейтральной коннотацией и выступает в качестве «архилексемы семантического поля», представленной в толковых словарях энциклопедической информацией, конь имеет более высокую стилистическую окраску и характеризуется экспрессией; 2) негативная - позитивная окрашенность, реализуемая в переносных употреблениях этих слов (Химик 2014). Проведенный нами анализ подтверждает данный факт: в устойчивых сравнениях с компонентом «лошадь» преобладает отрицательная коннотация, обусловленная утилитарным отношением к животному: нагружать/нагрузить кого как лошадь; взваливать/взвалить что на кого как на лошадь; сопеть (пьхтеть) как (загнанная) лошадь; стоять как лошадь; ходить как спутанная (стреноженная) лошадь; тогда как в основе сравнений с конем лежит прежде всего представление о его силе, энергии, скорости: как норовистый (необъезженный) конь; бегать/носиться как кони; сильный, здоровый как конь; брыкаться как конь; устар. посл. человек убог - что конь без ног (Мокиенко, Никитина 2008).

Устойчивые выражения с зоонимическим компонентои «конь» («лошадь») в русском и сербском языках можно распределить по следующим тематическим группам:

- Отношение к лошадям. В славянской культуре конь всегда занимал важное место: верный помощник человека, он одновременно служил и в качестве транспорта, и в качестве рабочей силы. Такое отношение закрепилось в пословицах: Лошадь - человеку крылья (возит воду, возит и воеводу.); Кто лошадь завел - тот крылья обрел/ серб. Добар коњ - људска крила. Забота о лошади была одной из основных задач каждого крестьянина, что закрепилось в паремиях: От хозяйского глаза и конь добреет/ серб. Очи господареве - коње гоје (букв. От хозяйского глаза конь толстеет); Коню - овес, а земле навоз/ серб. 
Човеку вино, а коюу зоб (букв. Человеку - вино, а коню - овес), а также: На лошадь не плеть покупают, а овес; Не гони коня кнутом, а гони овсом; Не накормив коня, далеко не уедешь; Коня гладь не рукой, а овсом и мукой; От избытка овса конь слабеет и т.п. Как видим, в русском языке пословиц, посвященных уходу за лошадьми, значительно больше, чем в сербском. При этом народная мудрость советует не только заботиться о лошадях, но и остерегаться их как животных своенравных и не всегда покорных: Ломадь холь, корми, как сына, а берегись, как ворога/ серб. Храни коња као брата, а јаши га као душманина (букв. Лошадь надо кормить, как брата, а ездить на нём - как на враге); Жалеть коня - истомить себя/ серб. Кон се жив једе (букв. Ешь коня, пока он жив); Добрую лошадь одной рукой бей, другою слезы утирай/ серб. Док се плаши дотле га јаши (букв. До тех пор, пока конь боится - надо ездить на нём верхом).

В русском языке особо выделяется группа так называемых «казачьих» пословиц, имеющих ярко выраженный национальный характер и не имеющих эквивалентов в сербском языке: Казак без коня, что воин без ружья (конь для казака как часть вооружения); Казак с конём и ночью и днём (казак и конь неразлучны); Казак дружбу соблюдает: в беде коня не покидает (казак и конь вместе всегда); Казак сам не съест, а коня накормит (конь у казака на первом месте).

- Человек - труд. И в русской, и в сербской языковой картине мира конь характеризуется выносливостью и высокой работоспособностью. Соответственно в обоих языках возникли такие устойчивые сравнения, как работать как лошадь (реже конь)/ серб. Радити као коњ.

В данной группе наиболее ярко обнаруживается отмеченное выше противопоставление лошадь - конь в русском языке, именно поэтому чаще всего используется лексема «лошадь»' : рабочая лошадка; не гони лошадей; пахать как (ломовая) лошадь. Последний пример используется для характеристики прежде всего женщины, несущей на себе бремя изнурительной физической или умственной работы. В основе подобных выражений лежит метафора, уподобляющая человека, занимающегося тяжёлой работой, домашнему животному-тяжеловозу. В русском языке достаточно много пословиц с той же основой. Приведём несколько примеров: На ретивую лошадь не кнут, а вожжи; Бойкой лошади - овес, ленивой - погонялка; От работы и лотади дохнут. Пословица От работы и лошади (кони) дохнут используется, когда шутливо или с пренебрежением говорят о работе того, чьё усердие не одобряют (то же самое, что и Работа дураков любит). Сходную структуру и значение имеет сербская пословица Које кљусе највише вуче, највише батина извуче (букв. Кляча, которая больше всего на себе тянет, получает больше побоев). Другими словами, тот, кто больше всех работает, страдает первым. Как видим, и в сербском примере негативная оценка репрезентирована с помощью другой лексемы - кљусе, т.е. коњ ниског раста; слаб и мршав коњ (букв. лошадь низкого роста, слабая и худая лошадь, лошаденка, кляча) (РС 1967).

В сербской традиции образ коня, связанный с работой и трудолюбием, может иметь и отрицательную оценку, причём позитивную роль при этом будет играть

${ }^{1}$ Конь предназначен прежде всего для верховой езды, воинской доблести, но не для тяжелой гужевой работы: По коням! На белом коне въехать; Коней на переправе не меняют, богатырский конь (Химик 2014).

Славистика XXII/2 (2018) 
вол: Вазда ће бити, волови орали, а коюи зобали (букв. Всегда было так: волы пахали, а кони ели, т.е. одни работают, а другие наслаждаются) (Караџић 1985).

- Качественные соответствия - несоответствия. В обеих традициях умного, доброго и сильного человека сравнивают с хорошим конём: За хорошим конем пыль поднимается столбом/ серб. За добрим коњем прашина се диже. Качества такого человека скрыть невозможно: Хороший конь и под ветхой попоной виден/ серб. Добар се коњ и под лошим покривачем познаје. При этом однозначно отрицательно оценивается внешнее (формальное) подражание и внутреннее несоответствие описываемым качествам. Такая оценка репрезентирована в сравнениях с жабой или раком: Коня куют, а жаба лапы подставляет; Куда конь с копытом, туда и рак с клешнёй/ серб. Видела жаба да се коњи кују, па и она дигла ногу.

Злого человека в русской и сербской традициях сопоставляют с опасным конём и козлом, причём человек в этом сравнении оказывается опаснее животных: Берегись козла спереди, лошади сзади, а злого человека со всех сторон / серб. Јарича човек треба да се чува спреда, коњ о одостраг, а злог човека са сваке стране.

Особо подчеркивается сербами, что все недостатки доброго человека, мелкие и незначительные, не идут ни в какое сравнение с одним, но значительным и неустранимым недостатком, присущим нехорошему человеку: Добру коњу сто мана рђаву само једна (букв. У хорошей лошади сто недостатков, у плохой только один).

Право на ошибку признается и русскими, и сербами. Как гласит русская пословица, конь (u) о четырёх ногах, да (и тот) спотыкается. Эта пословица используется как оправдание за совершённую ошибку или в качестве утешения при неудаче (Мокиенко 2012). В сербском языке семантическим эквивалентом может быть пословица И кою од сто дуката посрне (букв. И конь за сто дукатов может споткнуться/ упасть) (Караџић 1985).

О способном человеке сербы говорят: И он може и коњ му може (букв. И он может, и конь его может, т.е. хорошему, способному человеку все по плечу. Но иногда человек не в силах справиться со всеми проблемами, и тогда эта пословица расширяется: И ја могу, и коњ ми може, али бог ми не да (букв. И я могу, и конь может, но бог не дает).

С другой стороны, в качестве порицания за неспособность к выполнению какого-либо дела, лень и нежелание работать в сербском языке используется выражение Рђавоме коњу и седло је тешко (букв. Плохому коню и седло тяжело) и, что примечательно, его гендерный аналог Рђавој кобили самар досади (букв. Плохой кобыле и седло надоело/ наскучило), не имеющие эквивалентов в русском языке, если не брать во внимание примеры, выходящие за пределы литературного языка.

Об упрямом человеке и в русском, и в сербском языке чаще всего говорят, используя сравнения - упрямый как бык, осёл или баран. Однако в русском языке встречаются и пословицы с компонентом «упрямая лошадка»: Лошадка упряма, да везет прямо; Добр конь, да норовеи есть - упрямый. При этом образ лошади превращает упрямство в положительное качество. 
В сербском языке есть пословица Коња с магарием не ваља поредити (букв. Коня с ослом нельзя сравнивать, т.е. нельзя сравнивать разные качества), причём осёл здесь традиционно воплощает упрямство, а конь - силу и пользу в работе (ср. рус. Лошадка упряма, да везет прямо).

Только в сербском языке зооним «коњ» используется для характеристики таких качеств, как глупость и трусость: Види какав је ко кукавички коґ (букв. Смотри, он как трусливый конь); глуп као коњ.

О необходимости адекватной оценки своих возможностей гласит следующая сербская пословица: Где се велики коњи тркају, ту малима трбуси пуцају (букв. Там, где великие кони соревнуются в беге, у маленьких животы лопаются т.е. малый не может сравниться с великим).

В сербском языке обнаруживается и пословица, использующаяся для положительной оценки собственных качеств: И ми коња за трку имамо (букв. И у нас есть лошадь для участия в пробеге) в значении «и у нас есть возможность похвастаться чём-нибудь, мы сами не хуже других», которую на русский язык можно перевести с помощью выражения $\mathrm{Mbl} \mathrm{и} \mathrm{сами} \mathrm{с} \mathrm{усами.}$

- Дружба. В русской традиции конь узнаётся во время езды, а друг - в беде: Коня в рати узнаёшь, а друга в беде; Ломадь узнаешь во время езды; человека узнаешь во время знакомства. В сербском языке семантическим эквивалентом подобных выражений является пословица Пријатељ се у невољи познаје као злато у ватри, в которой дружба сравнивается с золотом, которое проверяется огнем.

- Мужчина - женщина. Мужское начало и в русском, и в сербском языках нередко репрезентируется с помощью рассматриваемых зоонимов, однако выраженных преимущественно другими лексемами (жеребеи/ серб. пастув - молодой энергичный мужчина) (Бытотова 2013). Особо выделяется тип молодящегося мужчины, о котором сербы говорят так: Ако је бог узео коњу ноге, није юисак (букв. Если бог лишил коня ног, то не лишил ржания). Мужчину часто сравнивают с конём и по его отношению к женщинам: И матор коњ зарже кад види младу кобилу (букв. И старый конь ржёт, когда видит молодую кобылу)/ ср. рус. мышиный жеребчик (молодящийся старый волокита).

Применительно к женщине устойчивые выражения, включающие в свой состав рассматриваемый зооним, чаще всего имеют ярко выраженную отрицательную коннотацию, обусловленную указанием на их внешнее сходство в лице, фигуре и репрезентированную в русском языке с помощью негативно окрашенных лексем: старая кляча/ серб. матора кобила; красива как кобыла сива и под. Однако в русском языке обнаруживается и выражение, использующееся в отношении женщины с положительной оценкой ее качеств - коня на скаку остановит, не имеющее эквивалента в сербском.

Об отношениях между мужчиной и женщиной русские и сербы говорят: Жену и коня никому не доверяй / серб. Жену, пушку и коюа човек може показивати, али у наруч не давати (букв. Жену, ружьё и коня показывай, но в пользование не давай). Русская пословица Кто ищет лошадей и женщин без недостатков, тот не будет никогда иметь коня в конюшне, а в доме -жены нашла 
отражение в сербском языке в шутливой форме: Ко тражи жену без мане и коња без грешке, живеће сам и ходаће пешке (букв. Кто ищет лошадей и женщин без недостатков, тот останется один и будет ходить пешком).

- Опыт - мудрость. Сходное значение и структуру в обоих языках имеют пословицы, указывающие на опыт человека: Старый конь бразды не испортит; Старый конь мимо не ступит/ серб. Стари коњ не учи се да врие (букв. Старого коня не учат молотьбе), Стари коњ се не учи играти (букв. Старого коня не учат танцевать). С другой стороны, в сербском языке обнаруживается и выражение, противоположное по семантике: Старог коња не можеш научити новим триковима (букв. Старого коня не можешь научить новым трюкам).

- Реакция на события. Полное структурное и семантическое совпадение в русском и сербском языках обнаруживается в примере Дарёному (даровому) коню в зубы не смотрят/ серб. Даровноме кону зуби се не гледају. Говорят, когда получают подарок, который не очень нравится. Пословица основывается на старинном обычае, связанном с покупкой лошади, когда покупатель внимательно осматривал её зубы, чтобы определить возраст (Пермяков 1979).

- Выгодное - невыгодное положение. У известного обоим языкам выражения быть на коне в сербском языке имеется и антоним: Пасти с коња на магариа (букв. Упасть с коня на осла) в значении утратить прежнее более высокое положение, материальный достаток (Трофимкина 2005).

Только в сербском языке обнаруживаются пословицы, описывающие подчинённое, несвободное положение человека: Вежи коњ а где ти господар заповеда (букв. Вяжи коня, где хозяин тебе велит); Вежи коња ђе ти газда каже, па ма коњ а појели и курјаци (букв. Вяжи коня, где хозяйн тебе велит, хоть его и волки съедят, т.е. делай так, как тебе приказали).

Таким образом, сербские и русские паремии и фразеологизмы с зоонимическим компонентом «конь» («лошадь») в большинстве случаев обнаруживают структурно-семантическую общность. Однако в обоих языках имеются и различия в употреблении данного зоонима. Очевидно, что прежде всего он используется для описания характера человека, причём человек в этом сравнении может обладать как позитивными, так и негативными качествами.

В русском языке, по сравнению с сербским, обнаруживается большее число единиц о трудолюбивых лошадях (с положительной оценкой этого качества) $16 \%$ от общего числа проанализированных единиц (в сербском языке - только $9 \%$ ). Соответственно, в русском языке выше и количество паремий, описывающих хозяйскую заботу о лошадях (31\%). В сербском языке подобные выражения составляют $20 \%$.

В обеих культурах труд всегда был в почёте, однако слишком усердный труд и у русских, и у сербов вызывает насмешку. При этом в сербском языке олицетворением последнего является вол, а не лошадь, которая как существо более разумное предпочтёт такому изнурительному и чаще всего бесполезному труду отдых.

В сербском языке образ лошади преимущественно используется при описании таких качеств человека, как ум, опыт, способности и, как следствие, служит для характеристики его заслуг. К этой семантической группе относится $57 \%$ единиц (в русском языке подобным значением обладают 40\% единиц). 
Примечательно, что упрямство - качество, чаще всего оцениваемое славянами отрицательно, доказательством чему являются сравнения с бараном или ослом, - в паремиях с образом лошади получает в обеих культурах положительную оценку как качество, необходимое для достижения поставленной цели.

В обоих языках все устойчивые выражения в равной мере употребляются и по отношению к мужчине, и по отношению к женщине. В русском языке нами отмечен только один фразеологизм, использующийся преимущественно по отношению к женщине: как ломовая лошадь. С другой стороны, в сербском языке с точки зрения гендерных отличий выделяется несколько выражений, характеризующих мужчину (по возрасту, отношению к женщинам), тогда как в русском - только один и с другим лексическим репрезентантом.

В русском и сербском языках имеются специфичные и уникальные паремии. Именно поэтому для многих пословиц трудно найти эквиваленты в другом языке - многие из них культурно обусловлены («казачьи» пословицы - в русском языке, в сербском - пословицы, включающие в свой состав героев эпических песен $\left.{ }^{2}\right)$.

\section{Цитирана литература}

Бытотова, Л. И. «Отражение концепта «лошадь» в языковом сознании русских и хакасов (на материале пословиц и поговорок).» [В:] Филологические науки в России и за рубежом: материалы II Междунар. науч. конф. (г. СанктПетербург, ноябрь 2013 г.). Санкт-Петербург: Реноме, 2013, 40-44. - URL: https://moluch.ru/conf/phil/archive/106/4413/ (дата обращения: 18.01.2018).

Маслова, В. А. Лингвокультурология, учебное пособие для студентов высших учебных заведений. Москва: ACADEMIA, 2004.

Медведев, Ю. Большой иллюстрированный толковый словарь русского языка: современное написание, Москва: Аст: Транзиткнига, 2006.

Мокиенко, В. М. Давайте говорить правильно - Пословицы в современном русском языке, Москва: ОЛМА Медиа групп, 2012.

Мокиенко, В. М. (1989), Славянская фразеология. Москва: Высшая школа.

Мокиенко, В.М., Никитина Т.Г. Большой словарь русских народных сравнений, Москва: ЗАО «ОЛМА Медиа Групп», 2008.

Пермяков, Г. Л. Пословицы и поговорки народов востока: систематизированное собрание изречений двухсот народов, Москва: «Наука», 1979.

Химик, В.В. «Лошадь или конь? (опыт сравнительного лексикографического анализа).» Филологический класс 2 (36), 2014: 68-72.

Ярцева, В. Н. (гл. ред.). Лингвистический энциклопедический словарь (ЛЭС). Москва: Советская энциклопедия, 1990.

\section{Источники}

Даль, В. Пословицы русского народа в двух томах. Том первый, Москва: «Художественная литература», 1984.

${ }^{2}$ Например, Цикн о ко Дамјанов Зеленко, букв. «сдох как Дамьянов Зеленко»; кто-то погиб/ Дамьян - герой народных песен; Зеленко - его конь (Караџић 1985). 
Даль, В. Пословицы русского народа в двух томах. Том второй, Москва: «Художественная литература», 1984.

Жуков, В. П. Словарь русских пословиц и поговорок. Москва: «Русский язык», 2000.

Караџић, В. С. Српске народне пословице. Београд: Просвета-Нолит, 1985.

Оташевић, Ђ. Фразеолошки речник српског језика, Нови Сад: „Прометеј”, 2012.

Стевановић, М. и др. Речник српскохрватскога књижевног језика (РСЈ), Нови Сад: Матица српска, 1967.

Трофимкина, О. И. Сербохорватско-русский фразеологический словарь, Москва: «ВОСТОК-ЗАПАД», 2005.

Јелена Стошић, Олга А. Трапезњикова

\section{УПОРЕДНА АНАЛИЗА РУСКИХ И СРПСКИХ УСТАЉЕНИХ ИЗРАЗА СА ЗООНИМСКОМ КОМПОНЕНТОМ „КОЬ” (,ЛОШАДЬ”)}

Рад је посвећен анализи зоонима „коњ” у руској и српској језичкој слици света. Када су у питању лексеме које означавају животиње, коњ је једна од кључних фигура у руским и српским паремијама. Циљ овог рада је утврђивање како општих тако и појединачних особености функционисања зоонима „коњ” у паремијама двају словенска језика. Као материјал за истраживање користили смо руске и српске паремије, изреке и фразеологизме. Приликом анализе коришћена је контрастивна метода.

Кључне речи: коњ, језичка слика света, српски језик, руски језик, паремије. 